\title{
Hasanuddin Journal of Midwifery
}

Volume 1 Issue 1, February 2019

P-ISSN: 2654-3028, E-ISSN: 2654-2730

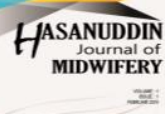

Pengaruh Latihan Fisik Terhadap Risiko Kardiometabolik (Trigliserida) pada Wanita Usia Reproduktif

\author{
Andi Ria Metasari ${ }^{1}$, Agussalim Bukhari ${ }^{2}$ \\ ${ }^{1}$ Bagian kebidanan, akademi kebidanan Lapatau Bone, email: andiriametasaribone@gmail.com \\ ${ }^{2}$ Fakultas Kedokteran, Universitas Hasanuddin Makassar
}

\section{Kata Kunci: \\ Latihan fisik, trigliserida}

Keywords:

Physical exercise,

Triglycerides level

\begin{abstract}
ABSTRAK
Kardiometabolik adalah faktor resiko terjadinya penyakit jantung diantaranya diabetes, obesitas, kolesterol, trigliserida serta tekanan darah tinggi. Penelitian ini bertujuan untuk mengetahui pengaruh latihan fisik terhadap faktor risiko kardiometabolik (trigliserida) pada wanita usia reproduktif di coastal area. Metode penelitian quasi eksperiment dengan rancangan metode one group pretest dan posttest design. Teknik pengambilan sampel secara purposive, dengan mengambil darah pada 117 wanita usia reproduktif, 61 coastal area dan 56 noncoastal area sebelum dan setelah melakukan latihan fisik berupa senam aerobik dan dilakukan sebanyak 3 kali dalam seminggu selama 8 minggu dengan durasi 60 menit guna pemeriksaan kadar trigliserida darah menggunakan alat spektrofotometer. Hasil yang didapatkan yaitu tidak ada perbedaan signifikan pada kadar trigliserida berdasarkan domisili repsonden dengan nilai $p=0.154$ yang artinya terdapat hubungan yang signifikan pada kategori kadar trigliserida sebelum dan sesudah responden melakukan latihan fisik (kategori batas normal dari 94 orang menjadi 114 orang, kategori batas tinggi dari 16 orang menjadi 3 orang, kategori tinggi dari 6 orang menjadi tidak ada, dan kategori sangat tinggi dari 1 orang menjadi tidak ada, dengan nilai $p=0.001$. Terdapat penurunan yang signifikan pada kadar trigliserida setelah responden melakukan latihan fisik $(122.83 \mathrm{mg} / \mathrm{dL} \pm 75.99$ menjadi $106.19 \mathrm{mg} / \mathrm{dL} \pm 29.86$, nilai $p=0.003)$. Dengan demikian, latihan fisik dapat menurunkan kadar trigliserida, sedangkan domisili di coastal dan noncoastal tidak berpengaruh terhadap kadar trigliserida.
\end{abstract}

\begin{abstract}
Cardio metabolic or metabolic syndromes are a group of risk factors that are directly related to the occurrence of heart disease, including diabetes and elevated levels of plasma glucose, obesity, cholesterol, triglycerides and high blood pressure. The research aimed to investigate the effect of the physical exercise on the cardiometabolic risk factor (triglyceride) of reproductive agewomen in the coastal area. The research used the quasi experimental method with one-group pre-test and post-test design. Samples were taken using the purposive sampling technique. The blood was taken on 117 reproductive age women (61 coastal area samples and 56 non coastal area samples) before and after the physical exercise to check the blood triglyceride
\end{abstract}


level using the spectrophotometer. The comparison of the triglyceride level between the samples dwelling in the coastal area and noncoastal area was only carried out before the physical exercise. The type of physical exercise was the aerobics gymnastic which was conducted 3 times a week for 8 weeks with a duration of 60 minutes. The research results indicate that there is no significant difference in the triglyceride level based on the respondents domicile with the value of $p=0.154$ that mean is the significant correlation between the triglyceride level category before and after the physical exercise (the normal category from 94 subjects to become 114 subjects, high limit category from 16 subjects to become 3 subjects, high category from 6 subjects to become none, and very high category from 1 subject to become none with the value of $p=0.001)$. There is a significant decrease on the triglyceride level after the physical exercise $(122.83 \mathrm{mg} / \mathrm{dL} \pm 75.99$ to become $106.19 \mathrm{mg} / \mathrm{dL} \pm$ $29.86, p=0.003)$. Therefore, the physical exercise can decrease the triglyceride level, whereas the coastal and noncoastal domiciles do not have an effect on the triglyceride level. 


\section{Latar Belakang}

Kardiometabolik atau yang biasa disebut dengan Sindrom Metabolik merupakan konstelasi yang berhubungan dari berbagai faktor antara lain biokimia, klinis, dan fisiologis serta metabolic. Hal ini dapat meningkatkan risiko kardiovaskuler, dan diabetes mellitus tipe 2 serta penyebab kematian lainnya. Beberapa gejala yang terdapat pada sindrom metabolic antara lain kadar High Density Lipoprotein (HDL) kolesterol darah yang mengalami penurunan, kadar trigliserida darah yang meningkat, obesitas sentral, tekanan darah tinggi, peningkatan kadar glukosa darah dan resistensi insulin. (Kaur, 2014)

Prevalensi sindrom metabolik bervariasi di tiap Negara. Berdasarkan data epidemiologi bahwa prevalensi sindrom metabolik dunia terdapat 20-25\%. Berdasarkan hasil penelitian Framingham Offspring Study pada responden yang berusia 26-82 tahun terdapat 29,4\% pria dan 23,1\% wanita yang mengalami sindrom metabolik. (Soegondo \&Purnamasari, 2010)

Berdasarkan Riskesdas 2013, terdapat 2,1\% yang menderita diabetes mellitus, obesitas sentral 26,6\%, hipertensi 9,5\%, dan penyakit jantung 1,5\%. Data provinsi Sulawesi-selatan dari tahun 2007 sampai tahun 2013, menunjukkan bahwa prevalensi diabetes melitus dari 0,8\% menjadi $3,4 \%, 0,8 \%$ menjadi $2,9 \%$ pada penyakit jantung, 5,9\% menjadi $10,5 \%$ pada hipertensi, dan dari $21,4 \%$ menjadi $30 \%$ pada obesitas sentral yang mana komponen ini berada di atas prevalensi ratarata nasional. (Riskesdas, 2013)

Pada usia produktif sangat rentan terjadi penyakit kardiometabolik seperti kardiovaskular. Hal ini disebabkan karena terjadinya perubahan komposisi tubuh berupa peningkatan massa lemak akibat umur yang bertambah, penurunan massa bebas lemak dan massa tulang, beban kerja yang berat, kurangnya aktivitas fisik, dan pola makan buruk dengan kadar karbohidrat dan lemak yang tinggi. (Nursalam, 2009)

Sekarang ini perkembangan ilmu pengetahuan dan teknologi memberikan andil sangat besar dalam gaya hidup masyarakat, terutama pada kalangan remaja. Dengan berkembangnya alat komunikasi yang canggih, remaja semakin malas melakukan kegiatan fisik, selalu ingin hal yang instan, hal itu menghabiskan waktu dengan alat komunikasi gadget mereka, ditambah lagi dengan kebiasaan mengkomsumsi makanan kurang sehat, akibatnya saat ini tidak sedikit remaja mengalami kelebihan berat badan (overweight) hal ini disebabkan karena timbunan makanan dan life style yang tidak diimbangi dengan olahraga teratur. Seseorang yang tergolong memiliki kelebihan berat badan (overweight) biasanya cenderung lebih rentang terkena penyakit jantung koroner, diabetes, osteoarthritis dan penyakit degenerative lainnya.Hal itu dapat terjadi karena penumpukan lemak dalam jaringan adipose (bawah kulit) dalam bentuk trigliserida, sehingga terjadi penyempitan pembuluh darah.Kadar trigliserida yang berlebih di dalam tubuh dapat membahayakan kesehatan. (Sutrisna dkk., 2017)

Pengaturan pola hidup sehat, lebih sering melakukan aktivitas fisik yang bersifat aerobik dan anaerobik, melakukan olahraga secara rutin adalah merupakan cara untuk mengatasi kelebihan lemak, kesegaran jasmani serta peningkatan kemampuan fungsional. Latihan fisik yang bersifat aerobik diantaranya jalan kaki, jogging, bersepeda, renang, senam aerobik dan lainnya. Dari jenis latihan aerobik yang dikemukakan, salah satunya adalah senam aerobik. Senam aerobik adalah latihan yang dilakukan untuk membakar lemak sambil memperbaiki kekencangan otot yang dipimpin oleh pelatih berpengalaman secara bersama-sama dengan diiringi musik yang sesuai dengan irama/gerakan untuk anggota tubuh yang bergerak. (Indah, 2016) 
Berdasarkan hasil penelitian Rembang dkk (2015) pada mahasiswa kedokteran tentang pengaruh senam terhadap kadar trigliserida darah menyatakan bahwa terjadi penurunan kadar trigliserida darah setelah melakukan senam.

Penelitian ini diharapkan dapat membantu menjadi sumber informasi karena masih kurangnya penelitian tentang kadar trigliserida yang dilakukan di Indonesia. Oleh karena itu, tentang pengaruh latihan fisik terhadap faktor risiko kardiometabolik (trigliserida)pada wanita usia reproduktif.

\section{Metode Penelitian}

Penelitian eksperimental dengan rancangan one-group pre-test and post-test design. Sampel yang digunakan sebanyak 117 orang. Teknik pengambilan sampel yaitu non probability sample dengan menggunakan metode purposive sampling dan telah memenuhi kriteria inklusi.

Pengukuran kadar trigliserida menggunakan alat spektrofometer. Data responden (umur dan domisili), Data konsumsi diukur dengan menggunakan food recall 24 jam minggu pertama, minggu keempat dan minggu ke delapan

Untuk menguji data berdistribusi normal/tidak menggunakan uji 41statisticnormalitas. Taraf signifikan $(\alpha=0,05)$. Jika $p<0,05$, maka Ho ditolak artinya data tidak berdistribusi normal. Penelitian ini menggunakan uji hipotesis mann whitney $U$, chi-square dan Wilcoxon

\section{Hasil penelitian dan Pembahasan \\ Hasil Penelitian}

\section{Analisis Univariat}

Tabel 1. Karakteristik responden berdasarkan domisili

\begin{tabular}{ccc}
\hline Tempat Tinggal & Frekuensi (n) & Presentase (\%) \\
\hline Coastal & 61 & 52,1 \\
Non Coastal & 56 & 47,9 \\
Jumlah & 117 & 100 \\
\hline
\end{tabular}

Tabel 1 menunjukkan bahwa dari 117 responden, terdapat 61 orang responden (52,1\%) yang tinggal di daerah coastal, dan 56 orang responden $(47,9 \%)$ yang tinggal di daerah noncoastal.

Tabel 2. Kadar trigliserida pre test dan post test

\begin{tabular}{lccccc}
\hline \multicolumn{2}{c}{ Kadar trigliserida pre test } & \multicolumn{3}{c}{ Kadar trigliserida post test } \\
\multicolumn{1}{c}{ Kategori } & $\mathbf{n}$ & $\mathbf{\%}$ & Kategori & $\mathbf{n}$ & $\mathbf{\%}$ \\
\hline Normal & 94 & 80,3 & Normal & 114 & 97,4 \\
Batas tinggi & 16 & 13,7 & Batas tinggi & 3 & 2,6 \\
Tinggi & 6 & 5,1 & & & \\
Sangat tinggi & 1 & 0,9 & & & \\
Jumlah & 117 & 100 & & 117 & 100 \\
\hline
\end{tabular}


Tabel 2 menunjukkan bahwa dari 117 responden dengan kategori kadar trigliserida pre-test, terdapat 94 orang $(80,3 \%)$ yang memiliki kadar trigliserida normal ,16 orang $(13,7 \%)$ kadar trigliserida batas tinggi, 6 orang (5,1\%) dengan kadar trigliserida tinggi dan 1 orang $(0,9 \%)$ dengan kadar sangat tinggi. Sedangkan kadar trigliserida post test dengan kadar normal sebanyak 114 orang $(97,4 \%)$ dan 3 orang $(2,6 \%)$ dengan kadar batas tinggi.

\section{Analisis Bivariat}

Tabel 3. Perbedaan kadar trigliserida berdasarkan domisili responden

\begin{tabular}{lcc}
\hline \multicolumn{1}{c}{ Variabel } & Median & Nilai P \\
\hline Kadar trigliserida coastal & 114.20 & \\
Kadar trigliserida noncoastal & 102.15 & 0.154 \\
& & \\
\hline
\end{tabular}

Tabel 3 menunjukkan hasil median kadar trigliserida berdasarkan domisili yaitu 111.30 dengan nilai $\mathrm{p}=0.154(\mathrm{p}>0.05)$ yang artinya tidak ada perbedaan yang signifikan pada kadar trigliserida berdasarkan domisili repsonden.

Tabel 4.Hubungan kategori kadar trigliserida pre dan pos test

\begin{tabular}{|c|c|c|c|c|c|c|c|c|c|c|c|}
\hline \multirow{3}{*}{ Variabel } & \multicolumn{8}{|c|}{ Kategori } & \multicolumn{2}{|c|}{ Total } & \multirow[t]{3}{*}{ Nilai P } \\
\hline & \multicolumn{2}{|c|}{ Normal } & \multicolumn{2}{|c|}{$\begin{array}{l}\text { Batas } \\
\text { tinggi }\end{array}$} & \multirow{2}{*}{$\begin{array}{c}\text { Tinggi } \\
\mathbf{n} \\
\end{array}$} & \multicolumn{3}{|c|}{$\begin{array}{c}\text { Sangat } \\
\text { tinggi }\end{array}$} & & & \\
\hline & $\mathbf{n}$ & $\%$ & n & $\%$ & & $\%$ & $\mathbf{n}$ & $\%$ & $\mathbf{n}$ & $\%$ & \\
\hline $\begin{array}{l}\text { Kadar } \\
\text { trigliserida } \\
\text { pre test }\end{array}$ & 94 & 80,3 & 16 & $\begin{array}{c}13 \\
7\end{array}$ & 6 & 5,1 & 1 & 0,9 & 117 & 100 & \\
\hline $\begin{array}{l}\text { Kadar } \\
\text { trigliserida } \\
\text { post test }\end{array}$ & $\begin{array}{c}11 \\
4\end{array}$ & 97,4 & 3 & 2,6 & 0 & 0 & 0 & 0 & 117 & 100 & 0.001 \\
\hline
\end{tabular}

Tabel 4 menunjukkan bahwa dari 117 responden dengan kadar trigliserida pre-test, terdapat 94 orang $(80,3 \%)$ yang memiliki kadar trigliserida normal, 16 orang $(13,7 \%)$ kadar trigliserida batas tinggi, 6 orang $(5,1 \%)$ dengan kadar trigliserida tinggi dan 1 orang $(0,9 \%)$ dengan kadar sangat tinggi. Sedangkan kadar trigliserida post test dengan kadar normal sebanyak 114 orang $(97,4 \%)$ dan 3 orang $(2,6 \%)$ dengan kadar batas tinggi. Sementara itu dalam tabel tersebut juga menunjukkan bahwa nilai $\mathrm{p}=0.001(\mathrm{p}<0.05)$ yang artinya terdapat hubungan signifikan antara kadar trigliserida sebelum dan sesudah melakukan latihan fisik (senam).

Tabel 5. Perbedaan kadar rata-rata trigliserida pre dan post test

\begin{tabular}{lllc}
\hline Variabel & Mean \pm SD & Median & Nilai P \\
\hline Kadar trigliserida pre & $122.83 \pm 75.99$ & 111.30 & \multirow{2}{*}{0.003} \\
Kadar trigliserida post & $106.19 \pm 29.86$ & 104.70 & \\
\hline
\end{tabular}


Tabel 5 menunjukkan hasil rata-rata kadar trigliserida pre test yaitu $122.83 \mathrm{mg} / \mathrm{dL}$ dengan standar deviasi sebesar \pm 75.99 dan kadar rata-rata trigliserida post test yaitu $106.19 \mathrm{mg} / \mathrm{dL}$ dengan standar deviasi sebesar \pm 29.86 . Adapun median pada kadar trigliserida pre test yaitu 111.30 dan median kadar trigliserida post test yaitu 104.70. Untuk mengetahui pengaruh latihan fisik terhadap kadar trigliserida maka digunakan Uji Wilcoxon, dengan nilai $\mathrm{p}=0.003(\mathrm{p}<0.05)$ yang artinya bahwa ada perbedaan yang signifikan antara kadar trigliserida sebelum dan setelah melakukan latihan fisik (senam).

\section{Pembahasan}

Penelitian ini menunjukkan terdapat pengaruh latihan fisik terhadap faktor risiko kardiometabolik (trigliserida) pada wanita usia reproduktif. Secara statistik, dengan uji Mann-Whitney $U$ menunjukkan hasil median kadar trigliserida di daerah coastal yaitu 114.20 dan median kadar trigliserida noncoastal yaitu 102.15 dengan nilai $\mathrm{p}=0.154(\mathrm{p}>0.05)$ yang berarti tidak terdapat perbedaan signifikan pada kadar trigliserida berdasarkan domisili repsonden. Hal ini mungkin terjadi karena tidak adanya perbedaan pola konsumsi makanan yang dapat mempengaruhi kadar trigliserida dalam tubuh seseorang baik di daerah coastal maupun noncoastal (Hamid dkk., 2013). Selain itu era masa kini akses perolehan bahan sumber pangan lebih mudah dikarenakan akses transportasi yang lebih mudah serta menjamurnya usaha jual beli seperti warung serta pedagang keliling setiap harinya yang menjual beraneka ragam kebutuhan makanan. Sehingga menjadikan tidak adanya perbedaan yang nyata pada tingkat ketersediaan pangan pada keluarga yang bertempat tinggal diwilayah coastal maupun noncoastal(Aulia dkk., 2015). Hasil penelitian Hamid dkk (2013), tidak ada perbedaan yang signifikan pada tingkat keragaman bahan makanan sumber protein nabati baik wilayah coastal maupun noncoastal.

Hasil uji Chi-square diperoleh nilai $\mathrm{p}=0.001(\mathrm{p}<0.05)$ yang artinya ada hubungan yang signifikan antara kadar trigliserida sebelum dan sesudah melakukan latihan fisik (senam). Responden yang diberikan intervensi berupa latihan fisik berupa senam aerobic didapatan bahwa hasil pengukuran kadar trigliserida pre test dan post test mengalami penurunan meskipun beberapa responden mengalami peningkatan kadar trigliserida karena disebabkan oleh banyak factor seperti sampel tidak mengikuti kegiatan latihan senam dengan baik, pola makan yang tidak teratur, intensitas dalam berolahraga yang sebaiknya dilakukan tiga kali dalam seminggu. Senam aerobik pada orang yang tidak terlatih menunjukkan bahwa terjadi penurunan komposisi lemak tubuh secara menyeluruh dan dapat meningkatkan kebugaran tubuh (Coso et al., 2010). Penelitian Elfiannisa (2016), di mana frekuensi latihan senam aerobik yang dilakukan lebih dari tiga kali dalam seminggu didapatkan pengaruh yang signifikan terhadap penurunan persentase lemak tubuh dan berat badan. Hal itu dikarenakan metabolisme lemak bekerja dengan baik. Hasil penelitian tersebut sesuai dengan penelitian yang Viveket al (2016), yang menyatakan bahwa adanya pengaruh pada latihan aerobik terhadap kadar HDL,LDL dan Trigliserida dalam waktu 8 minggu dengan durasi 45-60 menit yang dilakukan 3 kali seminggu.

Berdasarkan Uji Wilcoxon, diperoleh hasil nilai $\mathrm{p}=0.003(\mathrm{p}<0.05)$ yang artinya ada perbedaan yang signifikan antara kadar trigliserida sebelum dan sesudah latihan fisik (senam) di mana setelah dilakukan latihan fisik senam aerobik selama 8 minggu didapatkan penurunan kadar trigliserida darah yang pada pengambilan darah sebelum latihan dengan rata-rata $122.83 \mathrm{mg} / \mathrm{dL}$ menjadi 106.19 $\mathrm{mg} / \mathrm{dL}$. 
Penelitian lain yang dilakukan Sutrisna dkk (2017), menyatakan senam aerobik dapat menurunkan kadar trigliserida pada kelompok Body Mass Index (BMI) Normal siswa SMAN 3 Depok yang dilakukan selama 60 menit dengan rata-rata penurunan sebesar $62,7 \mathrm{mg} / \mathrm{dL}$ dan nilai t-hitung sebesar 20,41.

\section{Kesimpulan}

Kami menyimpulkan bahwa tidak terdapat perbedaan kadar trigliserida berdasarkan domisili responden. Disamping itu, terdapat hubungan yang signifikan kategori kadar trigliserida sebelum dan sesudah latihan fisik di mana ada perbedaan yang signifikan antara kadar trigliserida sebelum dan sesudah latihan fisik dengan nilai $p=0.003(p<0.05)$. Setelah dilakukannya penelitian ini diharapkan perlunya diadakan penelitian lanjut mengenai pengaruh latihan fisik dengan kadar trigliserida namun dibandingkan dengan kelompok kontrol.

\section{Ucapan Terima Kasih}

Ucapan terimakasih kepada ayahanda dan ibunda sebagai penyedia dana, motivator selama penelitian. Ucapan terima kasih kepada responden Mahasiwa Magister Kebidanan Angkatan VI Unhas dan Mahasiswa Akbid Tahirah Al Baeti Bulukumba yang telah bersedia berpartisipasi dalam penelitian ini serta pegawai/staff RS Universitas Hasanuddin Makassar yang sudah banyak membantu selama berlangsungnya penelitian. 


\section{Daftar Pustaka}

AuliyaC., K. H. WoroO.,\&B. I. (2015). Profil Status Gizi Balita ditinjau dari Topografi Wilayah Tempat Tinggal ( studi di Wilayah pantai dan Wilayah Punggung Bukit Kabupaten Jepara).Unnes Journal of Public Health, 4(2), pp. 108-116.

Coso JD., Hamouti N., Ortega JF., \&Ricardo MD. (2010). Aerobic fitness determines whole-body fat oxidation rate during exercise in the heat. Appl. Physiol Nutr Metab, 35: 741-748.

Elfiannisa.(2016). Perbedaan Pengaruh Frekuensi Latihan Senam Aerobik Terhadap Penurunan Persentase Lemak Tubuh Dan Berat Badan Pada Members Wanita. Medikora Vol. VX No. 1 April 2016, 39-51

Fitantra J.B. (2013). Pengaruh Olahraga Terhadap Metabolisme Trigliserida. Di unduh 1 Mei 2018. Available from: URL: HYPERLINKhttp://www.medicinesia.com/kedokterandasar/sel-dan-biomolekuler/pengaruh-olahraga-terhadap-metabolisme-trigliserida/

Indah D. (2016). Pengaruh Latihan Senam Aerobik Terhadap Penurunan Kadar Lemak Tubuh Anggota Senam Sanggar Kebugaran Muslimah Centre Padang. Jurnal Pendidikan Rokania, I(1) :1-9.

Kaur J. (2014).A comprehensive review on metabolic syndrome.Cardiology Research and Practice, 14(4): 1-21

Nursalam.(2009). Keperawatan Kesehatan Komunitas.Jakarta:Salemba Medika Rembang, A. A., Rampengan, J. J. V., \& Supit, S. (2015). Pengaruh Senam Zumba Terhadap Kadar Trigliserida Darah Pada Mahasiswa Fakultas Kedokteran Universitas Sam Ratulangi. E, 3(April).

Riskesdas.(2013). Riset Kesehatan Dasar. Badan Penelitian dan Pengembangan Kesehatan Kementerian Kesehatan RI

Soegondo S. \& Purnamasari D. (2010). 'Sindrom Metabolik', Dalam: Sudoyo, dkk,. Buku Ajar Ilmu Penyakit Dalam. ..., 4, pp. 88-93.

Sutrisna T., Setiakarnawijaya Y., \&Jauhari M. (2017). Perbandingan Efek Kerja Senam Aerobik Mix Impact Selama 60 Menit Terhadap Penurunan Kadar Trigliserida Dalam Darah Pada Kelompok Body Mass Index (Bmi) Overweight Dan Normal Siswa Sman 3 Depok. Jurnal Segar, 4(1)): 2580-9849

Vivek., Shanmugananth., Natraj P., \& Rekha K. (2016). a Study on the Effect of Step Aerobic Exercise on Blood Pressure, Heart Rate, Triglycerides, High Density Lipoprotein and Low Density Lipoprotein on a Patient With Acute Myocardial Infarction: a Case Study.International Journal of Physiotherapy and Research, 4(3):1546-1549 